Peran Pendidikan... Oleh: Samsudin

\title{
PERAN PENDIDIKAN AGAMA ISLAM DALAM MEMBENTUK KEPRIBADIAN DI ERA DISRUPSI
}

\author{
Oleh: \\ Samsudin \\ samsudinsamsudin231@gmail.com \\ STIT Islamiyah Karya Pembangunan Paron Ngawi
}

\section{Abstract}

Along the nun of year 2000 epoch progressively go forward. The progress bring big impact in human life. Do not all impact change of that epoch of goodness but also there is ugly. So that as generation router of nation have to can filter the impact rampant. Criminality action progressively, downhill nation moral progressively. For that, very required by weapon to decrease the mentioned. Many people which its personality concern. Many people which its personality concern. They understand law, but they also a lot impinge it. When wishing something select; choose by which instan do not want to strive.Education of Islam as one ofthe stock to follow motion progress of epoch so that forming of taft person. Personality everybody do not goodness, depended from its factors, especially environment ugly. Someone either or behaviour always become focus in society sophisticated. Technological progressively, many people imitating behaviour of public media. Education of Islam can form good moslem person can face multivariously of manner change of epoch. By having education of allocation Islam change of epoch can as medium to become sophisticated human being and water down life.

Seiring berjalannya tahun 2000 zaman semakin maju. Kemajuan tersebut membawa dampak yang besar dalam kehidupan manusia. Tidak semua dampak perubahan zaman itu baik namun juga ada yang buruk. Sehingga sebagai generasi penerus bangsa harus mampu menyaring dampak tersebut. Tindakan kriminalitas semakin 
merajalela, moral bangsa semakin menurun. Untuk itu, sangat dibutuhkan senjata untuk mengusut hal tersebut. Banyak orang yang kepribadiannya memprihatinkan. Mereka mengerti hukum, namun mereka juga banyak yang melanggarnya. Ketika menginginkan seseuatu pilih dengan cara yang instan tidak mau bekerja keras. Pendidikan agama Islam sebagai salah satu bekal untuk mengikuti gerak kemajuan zaman sehingga terbentuknya pribadi yang tangguh. Tidak semua orang berkepribadian baik, tergantung dari faktor-faktornya, terutama lingkungan. Tingkah laku seseorang baik maupun buruk selalu menjadi sorotan dalam masyarakat. Teknologi semakin canggih, banyak orang yang meniru tingkah laku dari media masa. Pendidikan agama Islam mampu membentuk pribadi muslim yang baik mampu menghadapi beraneka ragam perubahan zaman. Dengan bekal pendidikan agama Islam mampu mengalokasikan perubahan zaman sebagai sarana untuk menjadi manusia yang canggih dan mempermudah kehidupan.

Keywords: Islamic Religious Education, Personality.

\section{Pendahuluan}

Pendidikan sebagai salah satu sarana untuk membentuk pribadi seseorang dalam memaknai kehidupan. Melalui pendidikan manusia bisa melakukan perubahan yang akan terlihat pada kepribadiannya yang baik atau buruk dalam berinteraksi dengan lingkungannya. Pendidikan sangat menentukan maju tidaknya suatu bangsa. Jika pendidikan bangsa tersebut baik, maka bangsanya akan maju dan tentram. ${ }^{1}$ Pendidikan dengan kehidupan sosial masyarakat mempunyai

1 Ahmadi, Manajemen Kurikulum: Pendidikan Kecakapan Hidup (Yogyakarta: Pustaka Ifada, 2013), h. 1. 
hubungan timbal balik. ${ }^{2}$ Oleh karena itu, pendidikan mempunyai tanggung jawab penuh dalam mengantarkan para generasi penerus bangsa dalam menghadapi kemajuan zaman.

Bukan pada saat zaman milenial tiba, namun sejak tahun dahulu pendidikan mempunyai kontribusi yang banyak dalam kehidupan manusia untuk berkembang untuk dalam memperjuangkan eksistensinya dalam kehidupan mereka. Melalui proses pendidikan seseorang mampu berubah dan mereka mampu menjadikan karakter mereka menjadi lebih baik, mampu berkembang seiring dengan perkembangan zaman, mampu mengaplikasikan norma dan nilai yang baik, pembentukan kesadaran bangsa, mengentaskan keterbelakangan ekonomi, pengembangan pengetahuan dan teknologi serta segala bentuk peradaban manusia. Tiada perkembangan peradaban manusia tanpa adanya pendidikan. Sehingga dapat diketahui sungguh besarnya makna pendidikan bagi kehidupan manusia. Oleh karena itu, masyarakat berasumsi bahwa pendidikan merupakan salah satu instrumen dalam proses adaptasi dengan perkembangan zaman serta berbagai kemajuan peradaban bangsa. ${ }^{3}$

Pendidikan mempunyai fungsi yang sangat urgen dalam kehidupan manusia. Salah satu dari fungsi pendidikan adalah membantu manusia dalam proses membentuk jati diri dan melakukan proses mematangkan diri menuju terwujudnya kepribadian yang unggul sampai mencapai puncak kesempurnaan. ${ }^{4}$ Pendidikan agama Islam sangat urgen untuk mewujudkan karakter pribadi seseorang. Dalam pendidikan

2 M. Suyudi, Filsafat Pendidikan Islam: Kajian Filosofis dan Pemikiran Pendidikan Islam (Yogyakarta: Belukar, 2014), h. 39.

3 Hanun Asrohah dan Anas Amin Alamsyah, Buku Ajar Pengembangan Kurikulum, Cetakan ke-4 (Surabaya: Kopertais IV Press, 2012), h. 21.

${ }^{4}$ Mulyasana, D, Pendidikan Bermutu dan Berdaya Saing (Bandung: Remaja Rosdakarya, 2011). 
agama Islam diajarkan tentang hubungan dengan sang pencipta, sesama manusia dan alam. Seiring dengan perkembangan zaman yang semakin modern instrumen utama yang mampu menanggulangi munculnya perilaku negatif adalah melalui penanaman pendidikan agama Islam sejak usia dini.

Individu yang tak memiliki pemahaman agama akan secara taklid menerima pernyataan yang mereka terima, baik melalui media maupun lewat jejaring sosial mereka, yang lebih jauh mengakibatkan dirinya mengalami kerugian. Karena bagi mereka harta, kekayaaan, pangkatlah yang mampu mensejahterakan kehidupannya, bahkan tidak memikirkan kehidupan setelah kematian. Padahal agama menjadi bekal kehidupan di dunia sampai akhirat. Seorang yang benar-benar muslim harus selalu berpikir positif, bertutur kata yang baik dan berbuat semata-mata karena Allah, sebab hidup dan matinya telah diserahkan pada-Nya. Dalam kehidupan masyarakat, agama mempunyai tiga fungsi yang harus diperhatikan yaitu kebudayaan, sosial dan kepribadian. ${ }^{5}$

Pendidikan agama Islam merupakan proses dalam rangka membimbing dan mengasuh para peserta didik dengan harapan setelah lulus dari proses pendidikannya mereka mampu memahami isi kandungan dari ajaran agama Islam secara universal, menghayati makna dan maksud serta tujuannya dan pada akhirnya mereka bisa mengaplikasikan dalam kehidupan sehari-hari serta menjadikan ajaran-ajaran agama Islam yang telah dianutnya itu sebagai pedoman hidupnya sehingga mampu mendatangkan kesejahteraan dan kebahagiaan kehidupan dunia dan akhirat. $^{6}$ Pendidikan agama Islam mampu mengarahkan manusia untuk memahami aspek ketuhanan, spiritual dan dasar-

\footnotetext{
${ }^{5}$ Sri Ariyani, Agama dan Budaya (Yogyakarta : UGM), h. 4.

${ }^{6}$ Zakiyah Darajat, Ilmu Pendidikan Islam (Jakarta: Bumi Aksara, 2007), h. 88.

Volume 30 Nomor 1 Januari-Juni 2019 
dasar transenden yang mengelilingi secara tetap dalam dunia ini. $^{7}$

Pendidikan Agama Islam mempunyai makna ganda yakni: sebagai sebuah mata pelajaran di sekolah umum maupun madrasah. Isi pelajaran PAI meliputi Aqidah Akhlak, Fiqih, AlQur'an-Hadis, Sejarah Kebudayaan Islam dan Bahasa Arab seperti halnya yang diajarkan di pondok pesantren. Mata pelajaran PAI sangat penting dalam membentuk dan mengembangkan kepribadian seseorang. Pada setiap individu mempunyai perbedaan kepribadian, ada yang baik dan buruk. Salah satu tujuan Pendidikan Agama Islam adalah menumbuhkembangkan aspek kepribadian yang sempurna dengan berbagai proses.

Hakikat kepribadian seseorang itu terbentuk melalui proses yang panjang, tidak bisa terbentuk secara instan dan permanen. Namun kepribadian seseorang bisa berubah dengan berbagai proses salah satunya melalui pendidikan. Kepribadian itu mengalami perkembangan dan perubahan, sehingga membentuk pola yang tetap dan ciri khas dan keunikan pada setiap individu. Sehingga baik buruk, kuat lemahnya pribadi seseorang itu sangat dipengaruhi oleh berbagai faktor, baik faktor internal maupun eksternal. Dalam hal itu pendidikan mempunyai dampak yang kuat dalam membantu pembentukan pribadi seseorang. Kepribadian seseorang dapat terbentuk melalui beberapa aspek yaitu pembawaan atau hereditas, lingkungan dan citra diri.

Bersamaan dengan itu berkembang pula tingkat kecerdasan atau kebodohan psikis individu menentukan adaptasi kepemilikan bakat akan mempengaruhi tendensi dalam segala

7 Ahmadi, Evaluasi Kurikulum 2013 Persepektif Balance Scorecard (Ponorogo: STAIN Po PRESS, 2016), h. 3. 
sikap. ${ }^{8}$ Tingkat emosi pada seseorang bisa mempengaruhi proses perkembangan kepribadian karena emosional sangat erat hubungannya dengan dengan kondisi psikis seseorang. Dalam diri manusia terdapat unsur biologis dan psikologis yang keduanya merupakan unsur kepribadian manusia. Sehingga dapat disimpulkan bahwa salah satu pembentukan kepribadian seseorang adalah melalui Pendidikan Agama Islam.

Dalam prosesnya PAI mengajarkan tentang nilai-nilai ajaran Islam serta pribadi-pribadi yang baik, agar tercipta muslim yang sejati mempunyai kepribadian yang luhur. Pendidikan Islam sangat penting dalam bekal masa depan anak bangsa sebagai senjata melawan perubahan zaman. Melihat fenomena-fenomena yang terjadi sekarang ini sangat tragis. Zaman maju tetapi pribadi manusia banyak yang mundur. Mereka tega melakukan tindakan-tindakan kriminal tanpa memikirkan akibatnya. Ingin memiliki sesuatu namun malas untuk berusaha, lebih memilih mendapatkan sesuatu dengan cara yang instan tidak mau berpikir yang panjang.

Kemajuan zaman semakin menggebu-gebu, namun kenapa kejahatan juga semakin merajalela. Bahkan sesama muslim banyak terjadi perselisihan. Padahal sudah dijelaskan dalam hadits Nabi bahwa "muslim yang satu dengan muslim yang lainnya bagaikan bangunan yang saling menguatkan”. Tetapi, banyak terjadi pertikaian, penyalahgunaan narkoba, korupsi, pemerkosaan, bahkan pembunuhan. Pembunuhan terjadi di mana-mana, mayat dimasukkan ke dalam tong, lemari, mobil dan lain sebagainya. Di mana naluri mereka sampai tega membunuh saudara sendiri. Di masa sekolah mereka mendapatkan ilmu agama, namun mereka tidak bisa mengamalkan dalam kehidupan nyata. Pribadi mereka berubah seiring perubahan zaman.

\footnotetext{
${ }^{8}$ Muhibbin Syah, Psikologi Pendidikan dengan Pendekatan Baru (Bandung: Remaja Rosdakarya 1999), h. 233-235.
}

Volume 30 Nomor 1 Januari-Juni 2019 
Para generasi bangsa yang berada di zaman milenial sangat memberikan perhatian yang khusus. Mereka lebih memperhatikan teknologi yang semakin canggih dari pada memperhatikan ajaran agama Islam. Mereka lebih condong pada mbah google dari pada al-Quran. Memang teknologi lebih memudahkan dalam aktivitas sehari-hari, namun harus diiringi dengan pendidikan agama yang kuat untuk mengimbangi kemajuan zaman agar tidak terjerumus dalam kriminalitas dan dampak negatif lainnya.

Kenyataan ini perlu diperhatikan dan dikelola oleh guru dalam proses pembelajaran di kelas. Di sini guru perlu melakukan beberapa inovasi agar peserta didik lebih antusias dan berperan aktif dalam proses pembelajaran. Misalnya dengan melakukan pemanfaatan media digital atau media lainnya dalam proses pembelajaran. ${ }^{9}$ Dengan cara itu, maka guru akan mampu beradaptasi dengan tren peserta didik milenial yang mempunyai ciri khas dekat dengan teknologi atau gadget.

\section{Pembahasan}

\section{Pendidikan Agama Islam}

Pada sistem pendidikan di Indonesia, pendidikan agama Islam merupakan subjek mata pelajaran yang khusus dan dirancang untuk menanamkan nilai-nilai keislaman kepada peserta didik muslim. ${ }^{10}$ Pendidikan agama Islam merupakan sarana dalam proses membimbing dan membentuk peserta didik agar mereka bisa memahami dan mengaplikasikanbentuk-bentuk nilai ajaran agama Islam dalam kehidupan sehari-hari. Pendidikan agama Islam lebih menekankan dalam membentuk

\footnotetext{
${ }^{9}$ Edi Nurhidin, "Inovasi Pembelajaran Pendidikan Agama Islam (PAI) Melalui Pemanfaatan Media Pembelajaran Kontekstual Dan Pengembangan Budaya Religius Di Sekolah," KUTTAB 1, no. 1 (March 31, 2017): 1-14, https://doi.org/10.30736/kuttab.v1i1.95.

${ }^{10}$ Erwin Yudi Prahara, Materi Pendidikan Agama Islam (Ponorogo: STAIN Po PRESS, 2009), h. 6.
} 
muslim yang mempunyai kualitas kepribadian yang bermutu. Sehingga pendidikan agama Islam mempunyai fungsi sebagai berikut: ${ }^{11}$

a. Konvensional (meningkatkan komitmen dan perilaku yang berbeda-beda)

b. Neo konvensional (meningkatkan segala keragaman kehidupan sesuai akidah)

c. Konvensional tersembunyi (memberikan peluang dalam beragama sehingga harus bersifat netral dalam berbagai ajarannya)

d. Implisit (mengenalkan dalam aspek kehidupan secara terpadu)

e. Non konvensional (sebagai sarana untuk memahami

Salah satu tujuan dari pendidikan agama Islam adalah menumbuh kembangkan kepercayaan seorang muslim melalui pemberian, pemupukan, dan pengembangan pengetahuan, penghayatan, pengamalan, pembiasaan, serta pengalaman tentang isi kandungan ajaran agama Islam sehingga menjadi insan yang tingkat iman serta takwanya kepada sang pencipta selalu mengalami perkembangan seiring dengan berkembangnya usia. Pendidikan agama Islam memiliki berbagai macam tujuan baik dalam kehidupan sehari-hari maupun dalam kehidupan sosial. Adapun tujuan Pendidikan Agama Islam adalah untuk:

a. Menumbuhkembangkan akidah melalui pemberian, pemupukan, dan pengembangan pengetahuan, penghayatan, pengamalan, pembiasaan, serta pengalaman tentang agama Islam sehingga menjadi manusia muslim yang terus berkembang keimanan dan ketakwaannya kepada Allah SWT serta berakhlak mulia dalam kehidupan pribadi maupun sosial. Dengan demikian

${ }^{11}$ Prahara, Materi Pendidikan, h. 9-11. 
seseorang mampu mengembangkan daya pikirnya sehingga Allahlah sebagai segala sumber kehidupan.

b. Mewujudkan manusia Indonesia berakhlak mulia yaitu mampu meningkatkan berbagai keragaman dan siap mengembangkan sikap toleransi sesama manusia biarpun mempunyai perbedaan agama, suku dan budaya.

Pendidikan agama Islam mempunyai ruang lingkup yang meliputi keserasian, keselarasan, dan keseimbangan antara hubungan manusia dengan Sang Maha Pencipta, hubungan manusia dengan sesama manusia, dan ketiga hubungan manusia dengan dirinya sendiri, serta hubungan manusia dengan makhluk lain dan lingkungannya. Pendidikan agama Islam mempunyai wilayah yang luas dalam melakukan pendekatan dialogis untuk menanamkan kesadaran hidup bersama dalam rangka mengatasi keragaman dan perbedaan. Pendidikan ini berdiri atas dasar hubungan kesetaraan dan keseimbangan, saling percaya, saling memahami, dan menghargai persamaan, perbedaan dan keunikan, dan interdependensi. Hal ini merupakan penemuan yang baru serta perubahan yang integral dan komprehensif.

Pada hakikatnya ruang lingkup pendidikan agama Islam itu hampir sama dengan aspek-aspek pengajaran agama Islam karena materi dalam Pendidikan Agama Islam saling melengkapi antara satu sama lain. Jika diperhatikan dan ditelusuri materi yang dibahas maka ruang lingkup pendidikan agama Islam secara umum diterapkan dalam proses pembelajaran di sekolah adalah:

a. Pengajaran keimanan atau akidah

Iman merupakan segala sesuatu yang wajib diyakini dalam hati, diucapkan secara lisan dan diamalkan melalui angggota tubuh dalam kehidupan sehari-hari. ${ }^{12}$ Isi dari

${ }^{12}$ Yunahar Ilyas, Kuliah Aqidah Islam (Yogyakarta: Lembaga Pengkajian dan Pengalaman Islam (LPPI), 2010), h. 4. 
pelajaran akidah adalah mengajarkan kepada kita tentang kepercayaan tentang hal nyata maupun gaib, seperti halnya kita harus percaya adanya Allah, malaikat dan lainnya.

b. Pengajaran akhlak

Pengajaran akhlak adalah bentuk pengajaran yang bertujuan untuk membentuk sikap dan tingkah laku seseorang pada kehidupannya. Pada mata pelajaran akhlak seseorang dibimbing dan diarahkan tentang bagaimana berperilaku yang baik dalam setiap tindakan. Akhlak yang baik adalah akhlak yang berlandaskan al-quran dan Hadits Nabi. Etika standarnya adalah pertimbangan akal pikiran, moral dan standarnya adat kebiasaan yang umum berlaku di masyarakat. ${ }^{13}$

c. Pengajaran fikih

Pada materi fikih berisi tentang segala aspek dan tata cara dalam menjalankan ibadah serta pola kehidupan yang bersumber pada al-Quran, sunnah, dan dalil-dalil syar'i yang lain. Pengajaran fikih mempunyai tujuan agar seseorang mampu mengerti dan memahami dasar hukum Islam serta mampu mengaplikasikannya dalam kehidupan sehari-hari. Beribadah kepada Allah harus dilaksanakan dengan ikhlas dan merupakan pekerjaan hati yang bersifat rahasia. $^{14}$

d. Pengajaran al-Quran

Pengajaran al-Quran adalah pengajaran yang bertujuan agar siswa dapat membaca al-Quran secara benar baik makhraj maupun tajwidnya dan mampu mengetahui makna serta kandungan pada setiap ayat-ayat al-Quran. Akan tetapi dalam praktiknya hanya ayat-ayat

${ }^{13}$ Asy'ari, dkk, Pengantar Studi Islam (Surabaya : IAIN Sunan Ampel Press, 2005), h. 111.

${ }^{14}$ Abdul Hamid, Beni Ahmad Saebani, Fiqih Ibadah (Bandung : Pustaka Setia, 2009), h. 70. 
tertentu yang dimasukkan dalam materi pendidikan agama Islam yang disesuaikan dengan tingkat pendidikannya. Ayat al-Quran digunakan sebagai dalil-dalil tertentu.

e. Pengajaran sejarah Islam

Materi sejarah Islam bertujuan agar seseorang mampu memahami bagaimana perkembangan dan pertumbuhan agama Islam dari zaman dahulu hingga sekarang. Dengan sejarah Islam mereka bisa mengetahui bagaimana munculnya agama Islam sampai seluruh dunia.

\section{Kepribadian}

Kepribadian merupakan wujud yang tercermin pada diri seseorang dalam bentuk tingkah laku maupun kondisi kejiwaan dalam kehidupan sehari-hari. ${ }^{15}$ Sebagai bentuk tingkah laku dari proses hidup dalam seorang individu yang bebas, tergabung dalam masyarakat dan memiliki satu perasaan cemas dalam batin, yang mempunyai hubungan dengan religiusitas. ${ }^{16}$ Selain itu ada juga yang menyebutkan bahwa kepribadian sebagai bentuk tingkah laku, sifat, kebiasaan, kecakapan, bentuk tubuh, serta unsur-unsur psiko-fisik lainnya yang selalu menampakkan diri dalam kehidupan seseorang. ${ }^{17}$

Kepribadian sebagai wujud ciri khas watak seorang individu yang tetap, dengan kepribadian tersebut dapat diketahui ciri khas sebagai individu yang pasti. Pada faktanya setiap orang mempunyai ciri watak yang diperlihatkan secara jelas, konsisten dan konsekuen dalam setiap gerak-geriknya sehingga dapat dilihat bahwa seseorang tersebut memiliki mempunyai ciri khas yang berada dari individu-individu.

15 Jalaluddin, Teologi Pendidikan (Jakarta: Raja Grasindo Persada, 2001), h. 40.

${ }^{16}$ Ina Sastrowardoyo, Teori Kepribadian (Bumi Aksara, Jakarta, 1991), h. 36.

${ }^{17}$ Ahmad Fauzi, Psikologi Umum (Bandung: Pustaka Setia, 1997), h. 121. 
Peran Pendidikan... Oleh: Samsudin

Terbentuknya kepribadian berlangsung melalui perkembangan yang terus menerus. Pembentukan kepribadian melalui tiga proses, yaitu: pembiasaan, minat dan sikap serta rohani yang luhur. ${ }^{18}$ Dalam proses menumbuhkembangkan kepribadian anak, harus memperhatikan tentang beberapa aspek perkembangannya yaitu pertumbuhan fisik, perkembangan sosial dan perkembangan mental. ${ }^{19}$ Secara etimologis kepribadian dapat dilihat dari pengertian huwiyah, aniyah, dzattiyah, nafsiyyah, khuluqiyyah, dan syakhshiyyah. Biarpun dalam kata-kata tersebut mempunyai kesamaan, namun mempunyai sesuatu yang unik dan tersendiri. ${ }^{20}$

Pada hakikatnya kepribadian tidak terjadi secara mandiri. Namun, pada dasarnya kepribadian itu dibentuk melalui proses salah satunya melalui pendidikan, karena pendidikan menanamkan tingkah laku yang secara terus menerus dan berulang-ulang sehingga menjadi kebiasaan, ketika ia dijadikan norma, kebiasaan itu berubah menjadi adat, membentuk sifat, sifat-sifat seseorang merupakan tabiat atau watak, tabiat rohaniah dan sifat lahir membentuk kepribadian. Hal ini, sesuai dengan arti pendidikan, yaitu sebagai usaha sadar, teratur, dan sistematik yang dilakukan oleh orang-orang yang bertanggung jawab dalam mengajarkan ilmunya kepada anak agar mempunyai sifat dan watak sesuai dengan yang diharapkan oleh tujuan pendidikan. Kepribadian itu dapat dibentuk oleh pendidikan, dan pendidikan itu sendiri bersumber pada tiga

${ }^{18}$ Ahmad D. Marimba, Pengantar Filsafat Pendidikan Islam, cet. ke-8 (Bandung: PT. Al-Ma'arif, 1989), h. 88.

${ }^{19}$ Singgih D. Gunarsa, Psikologi Praktik Anak, Remaja dan Keluarga (Jakarta: Gunung Mulia, 2000), h. 105.

${ }^{20}$ Abdul Mujib, Kepribadian dalam Psikologi Islam (Jakarta: PT Raja Grafindo Persada, 2007), h. 18-19. 
pusat pendidikan, yaitu lingkungan keluarga, sekolah, dan masyarakat. $^{21}$

Pandangan konvergensi mengatakan kepribadian seseorang merupakan produk dari suatu proses yang dimulai pada saat orang itu dilahirkan dengan membawa bakat-bakatnya yang berlangsung secara terus menerus melalui pengalaman sampai pada saat tersebut. ${ }^{22}$ Freud berpendapat bahwa pada dasarnya kepribadian telah dibentuk pada akhir tahun kelima dan perkembangan selanjutnya sebagian besar hanya merupakan penghalusan struktur dasar itu. Kepribadian adalah organisasi dinamis dalam diri individul sebagai sistim psikofisis yang menentukan caranya yang khas dalam menyesuaikan diri terhadap lingkungan.

\section{Peningkatan Kepribadian Generasi Bangsa}

Bangsa merupkan suatu kumpulan masyarakat yang terbentuk dalam suatu wilayah yang sama dan mereka taat pada kedaulatan negaranya sebagai suatu kekuasaan tertinggi ke luar dan ke dalam mereka terikat oleh kegiatan negara. Sehingga dapat dikatakan setelah bernegara maka terwujudlah bangsa. ${ }^{23}$ Kualitas bangsa harus dijaga dan ditingkatkan melalui kepribadian masyarakat. Ketika zaman semakin berkembang maka harus diiringi juga dengan pribadi masyarakat yang baik dan dibangunlah kesadaran bersama. Tanpa kesadaran bangsa akan dirusak oleh perbuatan manusia itu sendiri yang berakibat hilangnya pribadi bangsa yang mulia bahkan sampai musnah ditelan arus modernisasi.

${ }^{21}$ Amir Daien Indrakusuma, Pengantar Ilmu Pendidikan (Surabaya: Usaha Nasional, 1973), h. 108.

${ }^{22}$ Ahmad Fauzi, Psikologi Umum.(Bandung: CV. Pustaka Setia, 1999), h. 164.

23 Arif Mansyuri, Kewarganegaraan.(Surabaya: Kopertais IV Jawa Timur, 2012), h. 56. 
Peningkatan kepribadian suatu bangsa dapat dilakukan melalui berbagai cara salah satunya penanaman pendidikan agama Islam sejak dini. Karena pendidikan agama Islam mengandung nilai-nilai ajaran Islam yang manfaatnya besar dalam kehidupan sehari-hari. Pendidikan agama Islam dapat dilaksanakan dalam lingkungan keluarga, sekolah dan masyarakat karena lingkungan tersebut memberikan pengaruh yang luas dalam pembentukan kepribadian seseorang. ${ }^{24}$ Pendidikan agama Islam bersifat progresif bukan hanya sekedar menyampaikan pengetahuan tetapi melatih kemampuan untuk berbuat sesuai dengan tuntutan lingkungan dan mampu menyesuaikan diri dari pengaruh ilmu pengetahuan dan teknologi. ${ }^{25}$

Pendidikan agama Islam dilakukan dalam rangka untuk memberikan bekal generasi bangsa agar mereka mampu mempersiapkan diri dalam meyakini, memahami, dan mengamalkan ajaran Islam dalam kehidupan. ${ }^{26}$ Pendidikan Islam memberikan perhatian yang besar dalam pembentukan individu yang berkepribadian muslim. Pendidikan agama Islam dalam membentuk kepribadian seseorang untuk menjadi insan yang unggul adalah menanamkan nilai akidah, ibadah dan akhlak. Sehingga terwujudnya generasi bangsa yang mempunyai pribadi luhur baik secara spiritual maupun sosial serta terciptanya negara yang bersatu, damai dan sejahtera.

Pendidikan Agama Islam berusaha membentuk karakter peserta didik agar menjadi insan yang mempunyai tingkat ketakwaan dan keimanan yang tinggi, berakhlakul karimah serta

24 Hasan Basri, Ilmu Pendidikan Islam (Bandung: Pustaka Setia, 2010), h. 261.

25 M. Suyudi, Pendidikan dalam Persepektif Al-Qur'an: Integrasi Epistemologi Bayani, Burhani dan Irfani (Yogyakarta: Mikraj, 2005), h. 62.

${ }^{26}$ Muhammad Alim, Pendidikan Agama Islam: Upaya Pembentukan Pemikiran dan Kepribadian Muslim (Bandung: PT Remaja Rosdakarya, 2006), h. 4.

Volume 30 Nomor 1 Januari-Juni 2019 
mampu meningkatkan kualitas ibadahnya kepada sang Pencipta. Akhlakul karimah itu meliputi etika, budi pekerti, dan moral sebagai perwujudan dari pendidikan Agama Islam. Peningkatan potensi spiritual mencakup pengenalan, pemahaman, dan penanaman nilai-nilai keagamaan, serta pengamalan nilai-nilai tersebut dalam kehidupan secara pribadi maupun secara umum di masyarakat. Peningkatan potensi spritual tersebut pada akhirnya bertujuan pada optimalisasi berbagai potensi yang dimiliki manusia yang aktualisasinya mencerminkan harkat dan martabatnya sebagai makhluk tuhan.

Pendidikan agama Islam diberikan dengan mengikuti perkembangan zaman bahwa agama diajarkan kepada manusia dengan visi untuk mewujudkan manusia yang bertakwa kepada Allah SWT dan berakhlak mulia, serta bertujuan untuk menghasilkan manusia yang jujur, adil, berbudi pekerti, etis, saling menghargai, disiplin, harmonis dan produktif, baik personal maupun sosial.

\section{Penutup}

Pendidikan agama Islam sebagai mata pelajaran di sekolah hingga perguruan tinggi harus terus dikembangkan agar tidak hanya menjadi formalitas. Tapi benar-benar mampu memberikan kontribusi pada pemikiran dan kepribadian generasi muda dalam menyikapi perkembangan zaman yang mempunyai dampak positif dan negatif. Berdasarkan penjelasan di atas, ada tiga poin penting yang perlu digaris bawahi. Pertama, pendidikan agama Islam mengajarkan tentang hubungan manusia dengan Allah, manusia dan alam semesta. Selain itu, juga mengajarkan akhlak mulia sehingga mampu mewujudkan pribadi muslim yang sejati. Kedua, pendidikan agama Islam mempunyai peran yang urgen dalam membentuk kepribadian seseorang sebagai alat dalam mengarungi kehidupan yang semakin maju sehingga mampu menilai diri dan 
kemauannya secara realistis serta mampu menghindar dari perilaku kriminalitas. Di era perubahan saat ini, PAI menjadi pondasi pembentuk kepribadian, agar tidak roboh diterpa derasnya arus modernisasi. Ketiga, kepribadian seseorang dibentuk melalui proses pendidikan, karena salah satu fungsi dari pendidikan adalah menanamkan tingkah laku secara terus menerus dan berulang-ulang sehingga menjadi kebiasaan dan membentuk sifat. Kepribadian seseorang terbentuk melalui proses yang panjang seiring dengan perkembangan. 


\section{DAFTAR PUSTAKA}

Ahmadi. Manajemen Kurikulum: Pendidikan Kecakapan Hidup. Yogyakarta: Pustaka Ifada, 2013.

Ahmadi. Evaluasi Kurikulum 2013 Perspektif Balance Scorecard. Ponorogo: STAIN Po PRESS, 2016.

Alim, Muhammad. Pendidikan Agama Islam (Upaya Pembentukan Pemikiran dan Kepribadian Muslim). Bandung: PT Remaja Rosdakarya, 2006.

Asrohah, Hanun dan Anas Amin Alamsyah. Buku Ajar Pengembangan Kurikulum, Cetakan ke-4. Surabaya: Kopertais IV Press, 2012.

Asy'ari, dkk. Pengantar Studi Islam. Surabaya : IAIN Sunan Ampel Press, 2005.

Basri, Hasan. Ilmu Pendidikan Islam. Bandung: Pustaka Setia, 2010.

Darajat, Zakiyah. Ilmu Pendidikan Islam. Jakarta: Bumi Aksara, 2007.

Fauzi, Ahmad. Psikologi Umum. Bandung: Pustaka Setia, 1997. . Psikologi Umum. Bandung: CV. Pustaka Setia, 1999.

Gunarsa, D. Singgih. Psikologi Praktik Anak, Remaja dan Keluarga. Jakarta: Gunung Mulia, 2000.

Hamid, Abdul dan Beni Ahmad Saebani. Fiqih Ibadah. Bandung: Pustaka Setia, 2009.

Ilyas, Yunahar. Kuliah Aqidah Islam. Yogyakarta: Lembaga Pengkajian dan Pengalaman Islam (LPPI), 2010.

Jalaluddin. Teologi Pendidikan. Jakarta: Raja Grafindo Persada, 2001.

Mansyuri, Arif. Kewarganegaraan. Surabaya: Kopertais IV Jawa Timur, 2012.

Mappiare, Andi. Psikologi Remaja. Surabaya: Usaha Nasional, 1982. 
Peran Pendidikan... Oleh: Samsudin

Marimba, Ahmad D. Pengantar Filsafat Pendidikan Islam. Bandung: PT. Al-Ma'arif, 1989.

Mujib,Abdul. Kepribadian dalam Psikologi Islam. Jakarta: PT Raja Grafindo Persada, 2007.

Mulyasana, D. Pendidikan Bermutu dan Berdaya Saing. Bandung: Remaja Rosdakarya, 2011.

Nurhidin, Edi. "Inovasi Pembelajaran Pendidikan Agama Islam (PAI) Melalui Pemanfaatan Media Pembelajaran Kontekstual Dan Pengembangan Budaya Religius Di Sekolah." KUTTAB 1, no. 1 (March 31, 2017): 1-14. https://doi.org/10.30736/kuttab.v1i1.95.

Sastrowardoyo, Ina. Teori Kepribadian. Jakarta: Bumi Aksara, 1991.

Suyudi, M. Pendidikan dalam Persepektif Al-Qur'an: Integrasi Epistemologi Bayani, Burhani dan Irfani. Yogyakarta: Mikraj, 2005.

-Filsafat Pendidikan Islam: Kajian Filosofis dan Pemikiran Pendidikan Islam. Yogyakarta: Belukar, 2015.

Syah, Muhibbin. Psikologi Pendidikan dengan Pendekatan Baru. Bandung: Remaja Rosdakarya, 1999. 